\title{
DARI IAIN KE UIN PANGERAN ANTASARI: TANTANGAN DAN PELUANG DI TENGAH ARUS PERUBAHAN SOSIAL DAN BUDAYA
}

\author{
Mujiburrahman* \\ IAIN Antasari Jalan Ahmad Yani km. 4.5 Banjarmasin \\ e-mail:mujiburrahman@iain-antasari.ac.id
}

\begin{abstract}
Abstrack
This paper analyzes the factors that drive transformation IAIN Antasari into UIN Pangeran Antasari. These changes are caused by transforming the madrasa curriculum, demand on work market that require a variety of skills as a result of modernization, social and cultural changes in globalization as impact from modern communication and transportation technologies and moral decacency in society. Transformation to UIN should consederate the integration of science and higher education access for all. UIN should answer society demand of religios passion and universal buman problem.
\end{abstract}

\begin{abstract}
Abstrak
Paper ini menganalisis faktor yang mendorong perubahan IAIN Antasari menjadi UIN. Perubahan tersebut disebabkan oleh perubahan kurikulum madrasah yang disamakan dengan sekolah, keragaman lapangan kerja yang menuntut aneka keahlian akibat modernisasi, perubahan sosial budaya di era globalisasi berkat teknologi komunikasi dan transportasi modern yang makin canggih dan krisis moral dan spiritual yang dialami masyarakat kontemporer. Perubahan menjadi UIN harus tetap memperhatikan integrasi ilmu yang tepat dan terbukanya akselibitas pendidikan tinggi bagi seluruh kalangan masyarakat. UIN juga harus mampu menjawab kebutuhan masyarakat terhadap agama dan menjawab persoalan kemanusiaan universal
\end{abstract}

Kata Kunci : Perubahan sosial, transformasi, sejarah, dikotomi, integrasi ilmu.

\footnotetext{
${ }^{*}$ Penulis adalah Dosen pada Fakultas Ushuluddin IAIN Antasari Banjarmasin
} 


\section{A. PENDAHULUAN}

Suatu hari di tahun 1996. Cendekiawan Muslim terkenal, Nurcholish Madjid (Cak Nur), memberikan ceramah ilmiah di kelas Program Pembibitan Dosen IAIN Se-Indonesia, yang bertempat di IAIN Syarif Hidayatullah (Syahid), Jakarta. Salah satu yang disinggung Cak Nur waktu itu adalah rencana transformasi IAIN menjadi UIN. Di luar dugaan, Cak Nur justru mengkhawatirkan rencana itu. "Saya khawatir orang-orang akan berbondong masuk ke fakultas-fakultas umum, sementara fakultas-fakultas agama peminatnya terus berkurang. Lebih berbahaya lagi jika orang-orang sisa yang tidak lulus di fakultas-fakultas umum, kemudian masuk ke fakultas agama. Akibatnya, kita akan melahirkan ulama-ulama sisa!" Demikianlah kurang lebih pernyataan Cak Nur di forum yang terbatas itu.

Di sisi lain, dua tokoh Muslim lainnya, yaitu Harun Nasution, yang kala itu menjadi Direktur Program Pascasarjana, dan M. Quraish Shihab, yang menjabat Rektor IAIN Syahid, berpandangan, transformasi IAIN ke UIN adalah suatu kewajaran, jika bukannya keharusan, karena pemisahan ilmu agama dan ilmu umum tidak sesuai dengan pandangan Islam yang mengintegrasikan keduanya. Harun Nasution seringkali menggambarkan kejayaan umat Islam di abad pertengahan, sebagai wujud nyata dari integrasi ilmu tersebut. Sementara M. Quraish Shihab, dalam sebuah seminar yang menghadirkan B.J. Habibie (kala itu sebagai Menristek) di IAIN Syahid, memaparkan berbagai penafsiran terhadap ayat-ayat Alqur'an dan Hadis, untuk mendukung gagasan integrasi ilmu, yang tentu saja didukung Habibie.

Meski kontroversi terus bergulir, perlahan-lahan, transformasi dua IAIN utama, yakni IAIN Syahid Jakarta dan IAIN Sunan Kalijaga, Yogyakarta, akhirnya terwujud pada 2002. Proses transformasi ini dipimpin oleh generasi yang lebih muda, yaitu Azyumardi Azra di Jakarta, dan M. Amin Abdullah di Yogyakarta. Menurut cerita Masykuri Abdillah (mantan Pembantu Rektor I UIN Syahid), ketika hendak menandatangani usul transformasi dua IAIN itu ke UIN, Menteri Agama M. Tholhah Hasan bukannya membaca bismillâbirrahmanirrahîm tetapi a'ûdzu billâbi minasy syaithânir rajîm. Jelas, hal ini menunjukkan bahwa Tholhah Hasan masih memiliki banyak kekhawatiran akan masa depan UIN. Kekhawatiran serupa juga dikatakan oleh A. Mukti Ali, mantan Menteri Agama, kepada saya ketika mewawancarai beliau (untuk keperluan riset disertasi) pada 28 September 2002.

Namun roda sejarah terus berputar, dan perubahan seolah tak dapat dibendung lagi. Beberapa IAIN lain, satu per satu mulai menyusul menjadi UIN. Pada 2005, dua lagi IAIN yang berubah jadi UIN, yaitu UIN Sunan Gunung Jati di Bandung dan UIN Alauddin di Makassar. Selanjutnya disusul oleh UIN Maulana Malik Ibrahim di Malang dan UIN Sultan Syarif Kasim di Pekanbaru. Yang paling baru, tahun ini (2013), adalah UIN Sunan Ampel, Surabaya dan UIN Arraniri, Banda Aceh. Barangkali, tahun depan (2014), akan segera disusul oleh Semarang dan Palembang. Mungkin pula, setelah itu akan disusul lagi oleh Banjarmasin, Padang dan Lampung. Meski Menteri Agama Maftuh Basyuni (20042009) sempat melakukan moratorium transformasi IAIN ke UIN, Menteri Agama sekarang, Surya Dharma Ali (2009-2014), tampaknya memberi dukungan penuh. 
Semua ini tentu menggoda kita untuk bertanya, mengapa transformasi IAIN atau bahkan STAIN ke UIN itu masih menyimpan keraguan di satu sisi, sementara di sisi lain gerakan untuk itu justru semakin kuat? Barangkali banyak jawaban yang bisa kita ajukan untuk pertanyaan ini. Dalam tulisan ini, saya akan mencoba melihatnya dari sudut perubahan sosial dan budaya masyarakat Islam Indonesia. Karena arah dari diskusi kita adalah perubahan IAIN Antasari menjadi UIN, maka di sini saya juga akan berusaha melihat perkembangan masyarakat di tingkat lokal, khususnya di kalangan masyarakat Banjar, warga yang paling dominan di Kalimantan Selatan (Kalsel).

\section{B. MENELUSURI AKAR-AKAR SEJARAH DIKOTOMI}

Masalah dikotomi ilmu, dan administrasi ganda pendidikan di negara kita (Kemendikbud dan Kemenag), jelas tidak muncul begitu saja dari perut bumi, atau tibatiba jatuh dari langit. Ada proses kesejarahan, yang dapat kita telusuri dalam jejak-jejak perubahan sosial budaya masyarakat kita, dari masa lampau hingga sekarang. Akar dari semua ini tampaknya adalah perjumpaan bangsa kita dengan kebudayaan Barat, paling kurang sejak abad ke 16, dan berlanjut hingga sekarang. Perjumpaan itu, bukan sekadar antara budaya Islam yang mulai intensif masuk sejak abad ke-13, tetapi juga dengan budaya India (Hindu-Budha), yang sudah datang terlebih dahulu, disamping budaya setempat.

Sikap kita yang ambivalen alias benci tapi rindu terhadap budaya Barat, antara lain didorong oleh kegetiran pengalaman berada dalam cengkeraman bangsa Barat yang menjajah kita di satu sisi, dan rasa iri terhadap kemajuan mereka di sisi lain (Mujiburrahman 2013). Surat-surat Kartini, Habis Gelap Terbitlab Terang (Pane 2005) yang ditulisnya menjelang akhir abad ke-19, menunjukkan sikap yang seperti itu. Sebagai anak bangsawan, ia bisa mendapatkan pendidikan modern ala Belanda. Ia ingin maju seperti orang-orang Belanda. Tetapi ia mengalami diskriminasi di dalam kelas, diremehkan oleh sebagian guru dan temannya, karena ia adalah pribumi, bukan kulit putih. Di sisi lain, ia juga harus berhadapan dengan tradisi Kraton Jawa yang sangat membatasi gerak-gerik perempuan. Kartini juga mengalami kegundahan ketika memikirkan ajaran-ajaran Islam yang dianutnya, khususnya perihal poligami, yang terjadi pada ibunya, dan tragisnya lagi, akhirnya juga menimpa dirinya.

Pada 1901, pemerintah kolonial Belanda secara resmi mulai menerapkan kebijakan 'politik etis', yaitu suatu upaya untuk memberikan pendidikan modern kepada bumiputera agar mereka kelak dapat berpartisipasi dalam kebudayaan Barat modern. Dapat dipahami jika masyarakat Indonesia ketika itu menunjukkan sikap yang berbeda- beda terhadap kebijakan ini (Mujiburrahman 2006). Pertama, kelompok yang menerima dengan senang hati. Sebagian dari mereka adalah kaum bangsawan, dan sebagian lagi adalah orang biasa, tetapi secara ekonomi cukup mampu. Kedua, kelompok yang menolak mentah-mentah, yaitu kalangan pesantren yang dipimpin ulama tradisional. Mereka tidak mau mengikuti kurikulum pemerintah kolonial, bahkan tidak mau mempelajari huruf Latin, dan mengharamkan memakai dasi, karena dianggap menyerupai orang kafir. Ketiga, kelompok 
yang menolak kurikulum Belanda, dan karena itu menolak subsidi pemerintah kolonial, tetapi pada saat yang sama, berusaha memasukkan berbagai pelajaran umum/Barat, yang diperkaya dengan pelajaran sejarah bangsa dengan titik tekan pada semangat nasionalisme dan perjuangan kemerdekaan. Kelompok ini tergabung dalam sekolah-sekolah Taman Siswa. Keempat, kelompok Muhammadiyah, yang menerima kurikulum pemerintah kolonial (sehingga bisa mendapatkan subsidi), tetapi menambahkannya dengan pelajaran agama Islam. Tujuan dari sekolah-sekolah Muhammadiyah antara lain adalah memodernisasi umat Islam melalui pendidikan dan menyaingi sekolah-sekolah missi Kristen yang juga mendapatkan subsidi pemerintah.

Ketika produk pendidikan politik etis mulai tampak dua hingga tiga dasawarsa berikutnya, ketegangan internal kaum intelektual mengenai masa depan kebudayaan Indonesia akhirnya muncul. Inilah yang dikenal dengan istilah 'polemik kebudayaan' (Mihardja 1948) di awal tahun 1930-an yang melibatkan S.T. Alisjahbana di satu pihak, dan tokoh-tokoh seperti Ki Hajar Dewantara (dari Taman Siswa) dan dr. Soetomo (dari Budhi Oetomo) di pihak lain. Takdir berargumen, karena Indonesia belum ada di masa lalu, maka kebudayaan Indonesia itu belum ada. Tugas para cendekiawan adalah menentukan ke arah mana kiranya kebudayaan Indonesia yang akan terwujud di masa depan. Bagi Takdir, kebudayaan Indonesia harus berkiblat ke Barat yang rasional, individualis dan materialis. Sementara bagi Soetomo dan Ki Hajar, kebudayaan Indonesia tidak harus berkiblat ke Barat, melainkan pada tradisi Timur yang tidak hanya menekankan rasionalitas, tetapi juga rasa, yang tidak individualis, tetapi kolektivis. Mungkin penting dicatat bahwa meskipun Ki Hajar adalah Muslim, dia sebenarnya lebih tertarik pada pendalaman mistik jawa (kejawen) dalam hidup spiritualnya.

Kalau kita perhatikan buku Polemik Kebudayaan, maka suara kalangan santri tampak tidak terwakili di dalamnya. Takdir memang ada sedikit menyebut kejayaan kebudayaan Islam klasik, tetapi hanya selintas. Sementara itu, di luar polemik Takdir, sebenarnya pada tahun 1937 telah terbit sebuah buku yang ditulis Mohammad Natsir berjudul Cultuur Islam yang oleh penulisnya "dihadapkan kepada pemoeda2 Islam perangkatan baroe" (Natsir 1937). Buku ini banyak berbicara tentang kejayaan kebudayaan Islam Arab di abad pertengahan dan hanya sedikit bicara tentang kebudayaan Islam Indonesia. Meskipun demikian, dapatlah kiranya ditafsirkan bahwa bagi Natsir kebudayaan Indonesia yang dicita-citakannya adalah kebudayaan yang berdasarkan Islam. Apalagi di dalam buku ini Natsir dengan bangga mengutip pernyataan orientalis H.A.R Gibb bahwa "Islam is indeed more than a system of theology, it is a complete civilization".

Di sisi lain, dalam pembuangannya di Banda Neira, Sutan Sjahrir (1951: 115) menulis pada akhir tahun 1936, bahwa Barat dan Timur itu tidak penting lagi. "Kita tidak perlu mengambil yang satu atau yang lain, kita boleh menolak kedua-duanya, oleh sebab keduanya harus silam dan sekarang ini sedang tenggelam ke masa silam," tulisnya. Dalam polemik itu, Sjahrir tampaknya adalah orang pertama yang mencoba menawarkan konsep universalisme kebudayaan berdasarkan prinsip kemanusiaan.

Tetapi angan-angan Sjahrir masih jauh dari kenyataan. Karya-karya sastra yang terbit pada periode ini, jelas menggambarkan ketegangan antara adat dan budaya Barat mod- 
Dari IAIN Ke UIN Pangeran Antasari: Tantangan dan Peluang di Tengah Arus Perubahan Sosial...

ern, seperti tercermin dalam Sitti Nurbaya karya Marah Rusli, Salab Asuban karya Abdul Muis dan Athies karya Achdiyat K. Mihardja. Ketegangan lain juga tampak antara adat dan Islam, seperti dalam roman Hamka, Di Bawah Lindungan Ka'bah dan Tenggelamnya Kapal van der Wijk. Ketegangan semacam ini bahkan terjadi bukan hanya dalam fiksi, tetapi dalam kenyataan yang sesungguhnya, seperti yang diceritakan Sutan Takdir Alisjahbana tentang dirinya dan ayahnya berikut ini:

One day, when I was about twenty-three, I found myself talking to him quite freely about the theories of the nineteenth century philosophers on such topics as evolution and the rise and fall of the great religions. My words cut my father to the heart; he understood that he would never now be able to eradicate these ideas from his son's mind, and so with a heart filled with an inexpressible grief, and with tears pouring down his face, he said: 'Ah, my son, we are not only divided in this world, but we shall never meet again in the next. Our Gods are different, and our worlds hereafter will be different' (Alisjahbana 1966 : 32-33).

Upaya keluar dari ketegangan-ketegangan itu, yang semula dirumuskan Sjahrir sebagai bukan Timur dan bukan Barat atau humanisme universal, akhirnya muncul kembali pada 1950, tepatnya ketika Asrul Sani dan kawan-kawan mengeluarkan Deklarasi Kelompok Gelanggang di majalah Siasat berbunyi:

Kami adalah abli waris yang sah dari kebudayaan dunia, dan kebudayaan ini kami teruskan dengan cara kami sendiri. Kalau kami berbicara tentang kebudayaan Indonesia, kami tidak ingat kepada melap-lap hasil kebudayaan lama sampai berkilat untuk dibanggakan, tetapi kami memikirkan suatu penghidupan kebudayaan baru yang sehat ( Sani 1997: 3-4).

Pada tahun 1950-1965, perdebatan mengenai arah kebudayaan Indonesia semakin ramai, terutama akibat pergumulan politik dalam negeri yang semakin hebat (Lindsay dan Liem 2012). Pertarungan antara kubu Manifes Kebudayaan (yang didukung oleh budayawan beraliran humanisme universal dan yang beraliran Islam), berhadapan dengan kubu Lekra (Lembaga Kebudayaan Rakyat) yang beraliran komunis, yang menyebut diri dengan 'sosialisme realis'. Dampak politik dari pertarungan ini begitu pahitnya. Di masa Soekarno, kubu Manifes yang jadi korban, sedangkan di masa awal Soeharto, kubu Lekra yang hancur lebur. Soal kebudayaan menjadi runcing akibat berselingkuh dengan politik.

Pada masa awal Orde Baru, politik kebudayaan pemerintah diarahkan untuk menggabungkan visi humanisme sekuler dengan kebudayaan jawa (abangan/priyayi), khususnya yang tercermin dalam buku tokoh Orde Baru, Ali Moertopo (1978) berjudul Strategi Kebudayaan. Buku yang diterbitkan CSIS (Centre for Strategic and International Studies) ini menggambarkan kebudayaan Indonesia secara esensialis. Konon kebudayaan asli Indonesia itu tercermin dalam Pancasila yang intinya sudah ada sejak sebelum datangnya agama-agama besar seperti Hindu, Buddha, Islam dan Kristen. Semua agama ini hanya memperkaya, tidak menghapuskan kebudayaan asli tersebut. Lebih lanjut, kebudayaan asli Indonesia itu tidak memperbolehkan konflik (baca: oposisi pada pemerintah) sebab ia menekankan nilai-nilai kekeluargaan, kerjasama dan harmoni.

Pandangan-pandangan Moertopo segera mendapat tanggapan keras dari H.M Rasjidi, Menteri Agama RI pertama (Rasjidi 1980). Rasjidi bahkan meragukan bahwa buku Strategi Kebudayaan ditulis sendiri oleh Moertopo. Ia mencurigai bahwa penulisnya adalah A.M.W. 
Pranarka, seorang intelektual Katolik di CSIS. Bagi Rasjidi, klaim-klaim yang dibuat buku itu tidak lebih dari upaya untuk memarginalkan posisi Islam dalam kebudayaan bangsa. Baginya, Islam bukan hanya memerkaya, melainkan mengubah kebudayaan masyarakat Indonesia. Tujuan dari buku ini, lanjut Rasjidi, sebenarnya adalah upaya mempertegas garis pemisah antara Muslim abangan dan Muslim santri belaka. Padahal menurutnya, kedua kelompok itu harus dianggap sebagai Muslim.

Sementara itu, sejak pertengahan tahun 1980-an, perkembangan ekonomi Indonesia yang semakin baik telah membuka peluang bagi munculnya Muslim kelas menengah. Sebagian dari mereka ini datang dari keluarga santri yang memperoleh pendidikan modern sekuler. Banyak di antara mereka itu ketika menjadi mahasiswa ikut aktif dalam kegiatan-kegiatan keislaman di kampus. Maka tak heran kalau kalangan kelas menengah Muslim ini kemudian mengembangkan budaya Islam yang berbeda dari kalangan bawah. Mereka misalnya naik haji dengan fasilitas mewah melalui $\mathrm{ONH}$ plus, suka membaca majalah-majalah pop Islam, dan memakai pakaian muslimah yang mahal dan modis. Di kalangan tertentu, mereka juga memproduksi karya-karya musik, sastra, novel, dan komik Islam sebagai alternatif dari produk-produk yang datang dari Barat atau Asia seperti Jepang, Korea dan India. Kelahiran ICMI di awal tahun 1990-an dan pesta budaya Islam yang dikenal dengan Festival Istiqlal seringkali dilihat sebagai wujud dari munculnya budaya kelas menengah santri di Indonesia.

Selain itu patut pula kiranya dicatat, sejak 1990-an pemikiran mengenai humanisme universal, semakin dikumandangkan bukan saja oleh kalangan sekuler, tetapi juga oleh kalangan santri. Dua tokoh pemikir Muslim Orde Baru, Nurcholish Majid (Cak Nur) dan Abdurrahman Wahid (Gus Dur), kedua-duanya berusaha menunjukkan bahwa Islam adalah bersifat universal humanis. Cak Nur menegaskan bahwa dalam arti generiknya, Islam sebagai kepasrahan kepada Tuhan, adalah agama umat manusia sepanjang masa, agama yang dibawa oleh semua Rasul, dan agama alam semesta. Sementara Gus Dur melihat, universalisme Islam itu ada pada tujuan-tujuan syariat yang lima (maqâshid alsyaria), yaitu menjaga keselamatan agama, jiwa, akal, harta dan keturunan (Mujiburrahman 1999 dan 2008).

\section{SEKILAS SEJARAH ISLAM DI MASYARAKAT BANJAR}

Jika demikian halnya perkembangan di Jawa, sebagai pusat perkembangan budaya dan politik nasional, bagaimanakah yang terjadi di Kalimantan Selatan? Dengan keterbatasan sumber-sumber kajian sejarah lokal yang ada, dapatlah kiranya dikatakan bahwa perjumpaan orang Banjar dengan Barat, seperti pada kesultanan lain di Nusantara, terjadi melalui perdagangan, yang berujung pada penjajahan. Sejak abad ke-16, tepatnya 1596, kesultanan Banjar sudah menjalin hubungan dagang dengan Belanda (VOC). Tetapi hubungan keduanya tidak selalu mulus. Pada 1607, seorang utusan VOC malah dibunuh oleh kesultanan Banjar, yang berakibat serangan balik Belanda pada 1612. Ini hanya salah satu contoh, yang terus berlanjut dalam banyak kasus perseteruan bersenjata antara keduanya. Pada abad ke-19, Belanda relatif sudah berhasil mendominasi kesultanan Banjar. 
Dari IAIN Ke UIN Pangeran Antasari: Tantangan dan Peluang di Tengah Arus Perubahan Sosial...

Namun, konflik internal di kalangan istana sendiri akhirnya mendorong pecahnya Perang Banjar, yang menjadi perang terlama dalam sejarah Indonesia, yaitu 47 tahun (1859-1906), setahun lebih lama dari Perang Jambi (1858-1904), dan delapan tahun dari Perang Aceh (1873-1912), meski yang terakhir lebih banyak menelan korban (Sjamsuddin 2001).

Boleh jadi, lamanya perlawanan itu menunjukkan suatu rasa permusuhan yang amat kuat dalam diri orang-orang Banjar terhadap Belanda. Meskipun tak dapat dipungkiri juga, sebagian kaum bangsawan dan ulama Banjar, kadangkala menunjukkan sikap kompromis terhadap kekuasaan Belanda yang de facto tidak bisa dikalahkan. Termasuk dalam hal ini adalah tokoh ulama Banjar paling berpengaruh, Muhammad Arsyad alBanjari (1710-1812). Dalam karyanya, Tubfat al-Râghibin (Al-Banjari 1983), ia memuji Sultan Tahmidullah, yang sebenarnya menjalin hubungan erat dengan Belanda. Sejauh yang saya ketahui, tidak ada pula tulisan Arsyad yang terang-terangan mengajak orang berjihad melawan Belanda. Tetapi semua ini tentu tidak menunjukkan bahwa ia menyukai Belanda. Kemungkinan besar, pertimbangan maslahat masyarakat secara keseluruhan, membuatnya memilih untuk tidak langsung menyentuh persoalan ini (Muthalib 1995: 10).

Kalau kita amati sejarah Perang Banjar, khususnya perlawanan yang dipimpin oleh Pangeran Antasari, tampak jelas bahwa unsur-unsur Islam turut memberikan sumbangan yang besar. Gerakan tarekat yang didukung oleh haji-haji, khususnya di Hulu Sungai, yang disebut dengan gerakan 'Baratib Baamal', merupakan pendukung perjuangan Antasari yang sangat kuat dan setia. Mereka meyakini bahwa perang melawan Belanda adalah jihad fi sabilillah. Tidak jelas, apa jenis tarekat Baratib Baamal itu. Martin van Bruinessen memperkirakan, ia adalah tarekat Samaniyah, karena anak Antasari, yang menjadi penerus perjuangannya, bernama Muhammad Seman (Bruinessen 1995 :66).

Kekuatan Islam tersebut tentu bukan sesuatu yang ada dengan sendirinya, melainkan melalui proses dakwah yang dilakukan oleh para ulama. Tak syak lagi, peran Muhammad Arsyad al-Banjari dan murid-muridnya sejak abad ke-18, sangatlah penting. Ketika pulang dari belajar Islam di Mekkah, atas dukungan Sultan, Arsyad kemudian menggelar pengajian di tempat khusus yang dikenal dengan wilayah Dalam Pagar. Sistem pembelajaran yang dilaksanakan Arsyad tampaknya tidak jauh berbeda dengan halaqah dalam pendidikan pesantren. Dalam model ini, seorang guru mengajar murid-muridnya dengan membacakan dan menerangkan sebuah kitab/teks. Tidak ada jenjang pendidikan berdasarkan kelas. Kita tidak tahu pasti, apakah sistem ini hanyalah peniruan dari apa yang dialami Arsyad dan kawan-kawannya di Mekkah, atau ada kaitannya dengan upaya 'mengislamkan' sistem pendidikan Hindu-Buddha yang sebelumnya mungkin sudah ada. Tetapi besar kemungkinan, yang terjadi adalah yang pertama.

Kira-kira hingga abad ke-19, pendidikan di Kalsel masih didominasi oleh pendidikan Islam model Arsyad al-Banjari. Salah satu pusat pendidikan Islam di luar Dalam Pagar, yang berkembang pesat mulai akhir abad ke-19 adalah di Nagara. Jaringan ulama Nagara dapat ditelusuri sampai ke Arsyad al-Banjari. Pada masa itu, di Nagara berkembang apa yang disebut langgar barangkap (musalla bertingkat dua), sejenis pesantren mini yang menjadi tempat penginapan santri sekaligus tempat ibadah dan belajar. Ulama asal Amuntai dan perintis Pesantren Rasyidiyah Khalidiyah, Abdurrasyid, pernah belajar di Nagara. Begitu 
pula, ulama terkenal dari Barabai, Muhammad Ramli, orangtua dari Mahfuz Amin, pendiri Pesantren Ibn al-Amin Pemangkih, juga pernah belajar di Nagara (Rahmadi dkk 2009: 168-178; Mandan 2008: 66-70).

Di awal abad ke-20, ada perubahan penting yang terjadi, yaitu orang-orang Nusantara, termasuk orang-orang Banjar, tidak lagi hanya pergi ke Haramain untuk menuntut ilmu, melainkan juga ke Mesir, tepatnya ke Universitas al-Azhar. Hal ini disebabkan karena Haramain telah dikuasai oleh Dinasti Ibnu Saud yang beraliran Wahabi, yang bagi kebanyakan mereka tidak cocok dengan paham keagamaan yang selama ini berkembang di tanah air. Namun di Mesir sendiri, mereka menemukan model pendidikan yang sudah diperbarui oleh Muhammad Abduh (1845-1905 M) dan Rasyid Ridha (1865-1935 M).

Sebenarnya, di abad ke-19 (1875-1889 M) sudah ada sekolah Belanda di Banjarmasin, dan tentu lebih berkembang lagi di awal abad ke-20 ketika kebijakan politik etis resmi dijalankan (Wajidi 2007). Mungkin karena bercermin kepada model pendidikan Belanda, lembaga-lembaga pendidikan Islam umumnya berupaya mengadaptasi pendidikan agama dengan model pendidikan sistem berkelas (klasikal), yang secara sederhana disebut sebagai perubahan dari bentuk pesantren atau pondok ke bentuk madrasah. Hal ini misalnya ditunjukkan oleh Pesantren Darussalam yang mulanya bernama Madrasah al-Imâd fi Ta'lim al-Awlâd, didirikan tahun 1914 oleh Tuan Guru H. Jamaluddin, dan Pesantren Rasyidiyah Khalidiyah yang didirikan Tuan Guru H. Abdurrasyid tahun 1922. Di sisi lain, pengajian tradisional halaqah tetap saja diteruskan, terutama di rumah-rumah Tuan Guru. Sementara itu, Tuan Guru H. Mahfuzh Amin yang mulai merintis Pondok Pesantren Ibn al-Amin di Pamangkih sejak 1941, tetap memertahankan sistem 'naik kitab' atau mangaji baduduk.

Pada periode ini pula, muncul sekolah-sekolah kaum pergerakan kemerdekaan yang berorientasi agama. Misalnya, pada dasawarsa kedua abad ke-20, H. As'ad, H. Mukhtar dan H. Mansur, mendirikan Persatuan Perguruan Islam (PPI) di Barabai. Dalam sekolah PPI, pelajaran agama dan umum digabung. Pada tahun 1914, komunitas Arab di Pasar Lama, Banjarmasin, mendirikan Arabische School. Pada mulanya, murid-murid sekolah ini terbatas pada orang-orang keturunan Arab. Tetapi kemudian mencakup juga orang-orang non-Arab. Tokoh-tokoh sekolah ini juga aktif di Sarekat Islam (SI). Para aktivis SI lainnya juga mendirikan sekolah bernama Madrasah al-Wathaniyyah. Sedangkan di Alabio, pada tahun 1925, Muhamadiyah mendirikan Standard School. Semua sekolah ini, disamping memberikan pelajaran agama, juga pelajaran umum seperti matematika, geograpi, sejarah, ilmu alam, dan bahasa asing (Syaharuddin 2008). Patut pula kiranya ditambahkan, di beberapa tempat di Kalsel, pemaduan ilmu umum dan agama itu dilakukan oleh dua lembaga pendidikan: pagi sekolah umum, sore sekolah agama, yang lazim disebut 'Sekolah Arab'.

Karena itu, tak salah kiranya kalau dikatakan, orientasi untuk memadukan pendidikan Islam dengan pendidikan modern cukup banyak mempengaruhi tokoh-tokoh pendidikan di daerah ini. Kalau kita perhatikan lembaga-lembaga pendidikan swasta yang bertebaran di Kalsel, yang didirikan di abad yang lalu, kita mungkin akan berkesimpulan bahwa mayoritas lembaga pendidikan Islam di Kalsel berorientasi pada integrasi. Pendidikan umum seperti SMP dan SMA, cenderung kurang diminati, khususnya di daerah Hulu Sungai. Adapun untuk Banjarmasin, yang sejak dulu cenderung kosmopolit dan 'dekat' 
dengan Belanda, keadaannya memang terbalik. Jumlah madrasah di kota ini kalah dengan jumlah sekolah umum. Namun secara keseluruhan, jumlah madrasah, terutama jika dimasukkan yang swasta, masih jauh lebih banyak. Data terbaru dalam Kementerian Agama RI dalam Angka 2012 (Anonim 2013) menyebutkan, di Kalsel terdapat 504 Madrasah Ibtidaiyah (143 negeri dan 361 swasta), 245 Madrasah Tsanawiyah (80 negeri dan 165 swasta), dan 95 Madrasah Aliyah (41 negeri dan 54 swasta).

Mungkin inilah salah satu sebab, pada paruh kedua abad ke-20, ada usaha-usaha ulama Banjar untuk mendirikan sebuah perguruan tinggi negeri khusus untuk kajian Islam. Inisiatif ini datang dari para ulama alumni Mesir dan Haramain. Akhirnya, sebuah Fakultas Agama Islam yang berafiliasi dengan Universitas Lambung Mangkurat didirikan pada 1958. Pada tahun-tahun berikutnya, fakultas ini berubah menjadi Fakultas Islamologi, lalu menjadi Fakultas Syariah cabang IAIN Sunan Kalijaga. Akhirnya, setelah melewati berbagai proses, pada 20 Nopember 1964, berdirilah IAIN Antasari Banjarmasin.

\section{TANTANGAN MENUJU UIN PANGERAN ANTASARI}

Kebanyakan mahasiswa IAIN Antasari, sebagaimana di PTAIN lainnya, adalah alumni madrasah, dan sebagian lagi alumni pesantren yang setara dengan madrasah. Karena itu pula, kebanyakan mahasiswa IAIN Antasari berasal dari daerah Hulu Sungai, di mana madrasah banyak berdiri. Tak salah pula kiranya jika dikatakan, kebanyakan mahasiswa IAIN Antasari berasal dari keluarga kelas menengah ke bawah, jika bukan dari keluarga yang benar-benar miskin. IAIN merupakan lembaga pendidikan tinggi dengan biaya relatif terjangkau bagi mereka. Melalui pendidikan IAIN, mereka akhirnya dapat melakukan mobilitas vertikal dalam strata sosial kehidupan masyarakat.

Tetapi IAIN, sebagaimana madrasah, yang telah berupaya memadukan ilmu-ilmu agama dan umum, mengalami banyak tantangan dan masalah, baik yang berasal dari dalam dirinya (internal) ataupun yang datang dari luar (eksternal). Secara internal, pengembangan IAIN tampaknya kalah cepat dengan perubahan yang terjadi pada madrasah-madrasah. Sejak diakuinya madrasah sebagai setara dengan sekolah dalam Undang Undang Pendidikan Nasional 1989, dan kemudian diteguhkan lagi dalam Undang Undang Sistem Pendidikan Nasional 2003, kurikulum madrasah sudah sama dengan sekolah, kecuali dengan tambahan pelajaran agama (akidah akhlak, sejarah Islam, Qur'an Hadis dan bahasa Arab). Dengan perubahan itu, maka alumni Madrasah Aliyah jurusan IPA, IPS dan Bahasa, memiliki peluang yang sama untuk melanjutkan studi di universitas umum. Akibatnya, banyak alumni madrasah, jika bukannya kebanyakan dari mereka, lebih memilih kuliah di universitas umum daripada di IAIN. Tak jarang pula terjadi, mereka mendaftar di IAIN dan universitas umum. Setelah mengetahui bahwa mereka lulus di kedua lembaga itu, mereka justru memilih universitas umum.

Di sisi lain, perubahan kurikulum madrasah di atas, menimbulkan masalah-masalah baru bagi IAIN. Salah satu masalah serius adalah semakin lemahnya wawasan ilmu agama yang dimiliki alumni MA saat ini. Mereka rata-rata tidak mampu membaca kitab kuning. Bahkan tidak jarang ditemukan alumni MA yang tidak pandai membaca Alqur'an dengan 
baik. Sebenarnya, dalam proses seleksi calon mahasiswa baru, telah diadakan tes kemampuan baca tulis Alqur'an. Namun karena target jumlah penerimaan mahasiswa cukup tinggi, mereka yang tidak lancar membaca Alqur'an pun tetap diluluskan. Jalan keluar yang diberikan adalah, memberikan pelajaran tambahan membaca Alqur'an kepada mahasiswa yang bersangkutan. Tetapi usaha-usaha ini ternyata tidak sepenuhnya berjalan mulus. Begitu pula, kursus yang diberikan untuk mahasiswa baru selama dua semester oleh Pusat Pelayanan Bahasa, tampaknya masih jauh dari kemampuan membaca kitab gundul. Karena itulah, muncul lagi upaya memberikan pendidikan metode tamyiz, atau magang di pesantren selama beberapa bulan. Semua ini menunjukkan bahwa IAIN sebagai pusat kajian Islam, menghadapi masalah serius perihal kemampuan calon-calon mahasiswanya, antara lain akibat kurikulum madrasah yang lebih banyak berisi pelajaran umum.

Harapan besar akhirnya tertuju pada alumni pesantren. Pesantren yang memiliki jenjang pendidikan yang setara dengan MA, dapat diterima di IAIN. Sayangnya, dalam kenyataan, ternyata para alumni pesantren yang masuk ke IAIN tidak pula berlimpah ruah. Sejumlah alumni pesantren tampaknya lebih suka langsung terjun ke masyarakat, atau melanjutkan studi ke Timur Tengah. Apalagi, ulama-ulama terkemuka di masyarakat Banjar hingga saat ini, yang pengajiannya dihadiri oleh ribuan orang, kebanyakan adalah alumni pesantren saja, bukan sarjana IAIN. Ini bukan berarti peran alumni IAIN sebagai ulama tidak ada sama sekali. Daftar khatib Jum'at di Kota Banjarmasin, misalnya, menunjukkan banyaknya alumni IAIN yang berperan sebagai khatib. Namun tampaknya ada kesan yang kuat di masyarakat, bahwa sarjana IAIN cenderung menjadi birokrat ketimbang ulama. Kalaulah menjadi ulama, mungkin lebih tepatnya disebut ulama-birokrat. Alhasil, sepertinya dalam pandangan masyarakat, kuliah di IAIN tidak lagi bertujuan untuk menjadikan anaknya ahli ilmu agama (ulama), melainkan menjadi PNS di Kementerian Agama atau di instansi lainnya.

Semua inilah kiranya yang mendasari kekhawatiran Nurcholish Madjid, Tholhah Hasan dan Mukti Ali yang dikemukakan di bagian awal tulisan ini, ketika menanggapi gagasan perubahan IAIN ke UIN. Mereka khawatir, jangan-jangan kajian-kajian keislaman akan mati dalam pelukan ibu kandungnya sendiri. Dalam beberapa tahun terakhir, Kementerian Agama memang sudah merespon kekhawatiran ini, dengan membuka program beasiswa Pendidikan Kader Ulama, termasuk di Fakultas Ushuluddin IAIN Antasari. Program ini sudah berjalan dari tahun 2005 hingga sekarang. Dalam proses perekrutan calon mahasiswa, jumlah pendaftar memang mengalami pasang surut. Begitu pula, dari sekitar 25-30 orang yang diterima, hanya separuh, bahkan kurang, yang memenuhi standar kemampuan bahasa asing yang memuaskan. Padahal, mereka umumnya berasal dari berbagai pesantren yang ada di Kalsel. Jika dengan program beasiswa saja begitu keadaannya, bagaimana pula jika tanpa beasiswa?

Karena itu sekali lagi kita patut bertanya, apakah masyarakat kurang mempercayai IAIN sebagai lembaga pendidikan kader ulama? Mungkin pertanyaan ini terlalu menohok dan kurang adil. Pertanyaan yang lebih adil barangkali adalah, apakah minat generasi muda untuk menjadi ulama semakin rendah? Jika pertanyaan ini kita ajukan ke alumni MA, kemungkinan besar, mayoritas akan menjawab 'ya'. Namun saya khawatir, jangan- 
Dari IAIN Ke UIN Pangeran Antasari: Tantangan dan Peluang di Tengah Arus Perubahan Sosial...

jangan mayoritas alumni pesantren juga memberikan jawaban serupa. Jika perkiraan ini benar, maka krisis ini tidak bisa hanya dilihat dari sisi internal lembaga-lembaga pendidikan Islam, melainkan juga sisi eksternalnya, yaitu perubahan sosial budaya secara luas di masyarakat.

Masyarakat Banjar, sebagaimana masyarakat lainnya, terus mengalami perubahan sosial yang cepat. Jumlah penduduk Indonesia dan dunia terus meningkat, meskipun program keluarga berencana cukup berhasil. Pada tahun 2011, penduduk Indonesia sudah mencapai 240 juta lebih (Suyono 2011). Penduduk Kalsel sendiri sudah mencapai 3,6 juta jiwa lebih. Ledakan jumlah penduduk ini tentu menimbulkan beragam masalah, antara lain urbanisasi. Lahan-lahan pertanian di desa mulai tidak cukup untuk dijadikan sandaran ekonomi keluarga. Orang-orang desa kemudian mencoba mengadu nasib ke kota. Maka tak heran jika Kota Banjarmasin, Banjarbaru dan Martapura, semakin padat saja. Kota Banjarmasin, yang luasnya $72 \mathrm{~km}$ persegi, sekarang sudah berpenduduk hampir $800 \mathrm{ribu}$ orang. Padahal kota ini terdiri dari banyak tanah rawa. Sementara itu, jumlah kendaraan di Kota Banjarmasin mencapai 250 ribu roda dua, dan 50 ribu roda empat, dengan pertambahan rata-rata 10\% per tahun (antaranews.com 26-9-2012). Makin padatnya kota ini, membuatnya mungkin tak layak lagi disebut Kota Seribu Sungai. Sampai awal 1980an, sungai-sungai kecil di Banjarmasin, termasuk kanal di dua sisi jalan Ahmad Yani, relatif masih berfungsi dengan baik. Tapi pada 2008, tak kurang dari 57 sungai lenyap. Pada 1995, masih ada 117 sungai, tapi pada 2000 tinggal 70 sungai. Pada 2002, sungai yang masih berfungsi tinggal 60 (Sukarni 2011: 51). Pada 2013 ini, mungkin jumlah sungai yang raib bertambah.

Mengapa orang suka pindah ke kota? Jawabnya, ada gula ada semut. Di kota, berbagai fasilitas modern tersedia, dan karena pembangunan seringkali terpusat di kota, lapangan pekerjaan juga lebih banyak di kota. Tetapi seiring dengan perubahan masyarakat, jenis pekerjaan yang ada juga makin beragam, dan makin menuntut keahlian khusus. Memang banyak pula pekerjaan di sektor informal, yang tersedia bagi para pekerja yang tidak memiliki keahlian khusus, namun sektor ini cenderung kurang menjanjikan. Karena itu wajar jika masyarakat semakin tertarik pada lembaga pendidikan yang menyiapkan alumninya untuk siap bekerja di berbagai lembaga modern. Menjadi ulama, guru atau PNS di Kementerian Agama, hanyalah sebagian di antara banyak pilihan yang ingin mereka ambil. Karena itu wajarlah jika kebanyakan alumni MA lebih berminat studi di universitas umum.

Di sisi lain, masyarakat kita juga mengalami perkembangan budaya yang penuh paradoks. Banyak pengamat berpendapat, sejak pertengahan 1980-an, Indonesia mengalami proses santrinisasi yang makin meningkat. Perempuan berjilbab semakin banyak, baik di kalangan swasta, sipil atau bahkan polisi dan tentara. Bank-bank syariah berdiri di mana-mana. Antrean naik haji makin panjang dan lama. Rombongan-rombongan umrah, seolah tiada putus. Pengajian-pengajian di masjid, langgar, majelis taklim, kantorkantor hingga rumah-rumah, sering dilaksanakan. Ramadan selalu disambut semarak, lebih-lebih di televisi. Tetapi di sisi lain, penyalahgunaan narkoba juga tinggi. Tempattempat hiburan malam makin ramai. Berbagai kejahatan seperti perampokan, pencurian hingga jambret, tak jarang kita dengar. Sementara itu, korupsi di lembaga eksekutif, legislatif 
dan yudikatif, terus marak. Tambang-tambang batubara, memang telah memberikan lapangan kerja bagi banyak orang. Segelintir pribadi bahkan menjadi sangat kaya raya. Tetapi di sisi lain, kerusakan lingkungan telah siap menghadang. Kebanyakan perusahaan tambang ditengarai tidak peduli dengan tanggungjawab reklamasi. Selain itu, ditengarai pula, uang panas hasil tambang sering dihabiskan untuk foya-foya dan maksiat. Paradoks dapat pula ditemukan di bidang sastra, antara sastra vulgar ala Ayu Utami, dengan sastra Islami ala Habiburrahman dan para penulis Forum Lingkar Pena (Kailani 2012).

Tantangan terasa makin berat karena generasi sekarang bukan lagi generasi mesin tik. Mereka adalah generasi elektronik, serba digital. Mereka benar-benar hidup di era globalisasi, ketika hubungan antar manusia begitu mudah, cepat dan murah, berkat teknologi komunikasi yang canggih. Dunia terbuka kepada mereka, melalui jari-jari mereka belaka. Dunia sudah menjadi datar, karena informasi dan komunikasi banyak yang bisa dilakukan tanpa harus melalui birokrasi hirarkis yang rumit, termasuk kritik kepada penguasa dalam urusan agama (lihat misalnya Feener 2013). Semua ini memberi peluang bagi mereka untuk menjadi baik atau buruk. Teknologi komunikasi, dapat membantu melipatgandakan dan mempercepat bukan hanya kebaikan, tetapi juga kejahatan. Sebagian dari kita mungkin bisa menahan diri, tidak masuk ke dalam dunia maya melalui alat-alat elektronik. Tetapi bagi anak cucu kita, hal ini sepertinya mustahil.

Salah satu dampak dari terbukanya dunia informasi ini adalah kegalauan pikiran. Anak-anak tidak hanya belajar dari buku-buku, tetapi juga dari internet dan televisi yang kadangkala memberikan informasi nilai-nilai yang bertentangan satu sama lain. Pendidikan guru di sekolah, dan orangtua di rumah, sangat mungkin bertentangan dengan apa yang anak-anak temukan di dunia maya. Generasi sekarang jauh lebih terekspose ke dalam keragaman, pluralitas pemikiran dan nilai. Dalam menyikapi keragaman ini, bagi yang sudah cukup dewasa, ia mungkin dapat berusaha memilih dan memilah. Sedangkan bagi yang suka berpikir sederhana, ia akan cenderung bersikap hitam-putih. Sementara anakanak yang masih labil, akan mudah terbawa arus, tergantung arah angin yang bertiup.

Berbagai kegalauan budaya dan akhlak ini, jelas memberikan tantangan sekaligus peluang bagi lembaga-lembaga pendidikan Islam, khususnya IAIN, untuk bisa menawarkan solusi. Transformasi IAIN ke UIN tentu diharapkan dapat memberikan tawaran-tawaran alternatif bagi kegalauan moral dan budaya yang dihadapi generasi muda. Tetapi hal ini bisa jadi pula berubah sebagai ancaman. Setelah berubah menjadi UIN, perilaku mahasiswanya dan wawasan budayanya, justru makin terbawa arus, ikut-ikutan dengan yang terjadi di universitas umum. Sementara itu, pembalikan bisa pula terjadi dari sudut lain, yaitu berupa radikalisasi keagamaan. Seolah sebagai respon balik atas kehidupan bebas dan permissif di masyarakat, sebagian anak-anak kampus justru menjadi aktivis keagamaan radikal, yang mengimpikan revolusi, dan sangat anti terhadap perbedaan paham keagamaan.

\section{E. PENUTUP}

Demikianlah, berdasarkan fakta-fakta sosial dan budaya yang telah dibahas di atas, seperti perubahan kurikulum madrasah yang disamakan dengan sekolah, keragaman lapangan kerja yang menuntut aneka keahlian akibat modernisasi, perubahan sosial budaya di era 
Dari IAIN Ke UIN Pangeran Antasari: Tantangan dan Peluang di Tengah Arus Perubahan Sosial...

globalisasi berkat teknologi komunikasi dan transportasi modern yang makin canggih, hingga krisis moral dan spiritual yang dialami masyarakat kontemporer, semua ini menunjukkan bahwa perubahan IAIN ke UIN adalah suatu keharusan sejarah. Cepat atau lambat, IAIN akan berubah ke UIN. Namun, untuk menyongsong perubahan itu, kita tidak boleh berpangku tangan dan terlena. Kita harus memikirkan bentuk dan isi UIN itu agar ia benarbenar berfungsi sebagaimana yang kita harapkan. Dalam hal ini, akan lebih bijaksana jika kita bersikap realistis (bukan pesimistis), yaitu mengukur kekuatan dan kelemahan kita, serta tantangan dan peluang yang tersedia. Dengan demikian, langkah-langkah yang akan kita ambil benar-benar berpijak pada kenyataan, bukan khayalan indah di atas langit belaka.

Salah satu masalah yang tetap krusial adalah integrasi ilmu. Usaha-usaha untuk mengintegrasikan ilmu-ilmu agama dan umum, sebenarnya sudah cukup lama dilakukan melalui pembaruan kurikulum madrasah. Tetapi usaha-usaha integrasi itu tampaknya tidak benar-benar berhasil, dan terkesan tambal sulam. Pelajaran umum dan pelajaran agama seolah berjalan sendiri-sendiri. Guru-guru agama, yang dididik di IAIN dan guru-guru umum yang dididik di universitas umum, seolah berjalan sendiri-sendiri. Saya katakan 'seolah' karena semua ini masih kesan, bukan hasil penelitian mendalam. Sejalan dengan kesan ini, alumni madrasah, jarangkali menjadi pintar di kedua bidang; umum dan agama. Yang banyak barangkali adalah pintar di bidang umum saja. Sebagian lagi malah serba tanggung; tidak benar-benar pandai di bidang umum, tidak pula di bidang agama. Karena itu, tampaknya Madrasah Aliyah Program Keagamaan (MAPK) yang dulu marak tahun 1990-an, perlu kiranya digalakkan lagi.

Pengalaman kita dengan madrasah cukuplah sebagai cermin untuk meramalkan, apa yang bakal terjadi kelak jika IAIN menjadi UIN, dari segi keilmuan. Jika kita tidak bisa meramu kurikulum dengan baik, dan tidak memiliki tenaga pendidik yang benar-benar menghayati integrasi keilmuan, maka tak salah lagi, kita akan melahirkan sarjana-sarjana tanggung pula. Lebih berat lagi adalah, ilmu-ilmu keislaman yang menjadi ciri utama IAIN selama ini, perlahan-lahan ditinggalkan orang, atau mutu kajiannya semakin menurun, karena makin langkanya calon mahasiswa yang berkualitas masuk ke prodi-prodi agama. Tentu saja, dua hal ini tidak kita inginkan. Kita mengimpikan, UIN nanti akan melahirkan sarjana yang ahli di bidang umum, tetapi berwawasan ilmu agama dan berakhlak mulia, atau ahli ilmu agama, yang berwawasan pengetahuan umum. Akan luar biasa, jika UIN bisa melahirkan, meski jumlahnya sedikit, seorang pakar bidang umum, tetapi sekaligus menguasai bidang agama. Untuk mencapai ini, barangkali kita perlu berkaca pada International Islamic University, Kuala Lumpur, yang mewajibkan mahasiswanya untuk menentukan bidang keahlian utama (major), dan bidang keahlian penunjang (minor). Jika major-nya di bidang umum, maka minor-nya harus bidang agama, atau sebaliknya. Pendapat lain menyarankan agar tiap-tiap prodi umum diberikan mata kuliah tafsir dan hadis tematik, sesuai bidang keilmuannya. Apapun pilihan kita nantinya, yang lebih penting lagi adalah adanya dialog antar-disiplin ilmu secara berkesinambungan, yang dilakukan oleh dosen-dosen dari berbagai bidang keahlian.

Selain itu, mengingat kebanyakan masyarakat kita adalah kelas menengah ke bawah, dan mereka inilah yang umumnya menjadi mahasiswa IAIN selama ini, maka sudah 
selayaknya kita memertimbangkan kebutuhan mereka. Secara umum, kita berharap, perubahan ke UIN tidak akan membuat biaya kuliah makin mahal, melainkan tetap terjangkau oleh mereka. Dengan demikian, peran UIN dalam membantu masyarakat kecil untuk mobilitas vertikal tetap terjaga dengan baik. Dalam konteks ini pula, patut dipikirkan jenis prodi-prodi yang akan dibuka kelak, yang diharapkan dapat memberi mereka ilmu dan keterampilan yang dibutuhkan oleh pasar tenaga kerja. Mungkin akan lebih baik jika kita memperbanyak prodi-prodi kejuruan di UIN nanti, guna merespons berbagai kebutuhan tenaga kerja yang makin beragam di masyarakat kontemporer. Apalagi, pada 2015 kita sudah memasuki pasar bebas ASEAN.

Di sisi lain, perkembangan sosial budaya masyarakat, tampaknya makin membutuhkan agama, sebagai pembimbing moral dan spiritual. Kecenderungan masyarakat kelas menengah kota untuk memasukkan anak-anak mereka di Sekolah Islam Terpadu misalnya, adalah petunjuk ke arah itu. Masyarakat sekarang membutuhkan pendidikan modern sekaligus tambatan moral dan spiritual agama. Transformasi IAIN ke UIN jelas sejalan dengan kecenderungan ini. Apalagi jika kita mengingat kecenderungan masyarakat Islam Banjar dalam bidang pendidikan, yang sejak dasawarsa awal abad ke-20, sudah terbuka kepada sistem pendidikan modern, dan cenderung kepada upaya-upaya integrasi ilmu. Dari sudut pandang ini, saya percaya, jika kelak IAIN Antasari berubah menjadi UIN, peminatnya akan sangat banyak.

Akhirnya, di era globalisasi ini, ketika dunia makin terasa kecil, dan hubungan antar manusia makin intensif, kecenderungan masa depan tiada lain adalah humanisme universal. Islam yang dikembangkan di UIN, hanya akan makin relevan, jika ia dapat menjawab persoalan-persoalan kemanusiaan universal. Penafsiran-penafsiran Islam yang sempit dan tertutup, cenderung akan mengerdilkan Islam itu sendiri. Pada saat yang sama, karena nilainilai kemanusiaan universal itu harus dioperasionalkan dalam konteks lokal, maka apresiasi terhadap kearifan lokal sangatlah perlu. Kajian terhadap khazanah tradisi Islam Banjar patut menjadi perhatian utama UIN Pangeran Antasari, sebagai salah satu ciri khas, yang membedakannya dengan PTAIN lain. Dengan demikian, kita bisa berpikir global, lalu bertindak lokal, dan sebaliknya, berpikir lokal, bertindak global. Mungkin mirip dengan cara berpikir kaum Sufi: melihat yang satu di dalam yang banyak, dan melihat yang banyak di dalam yang satu. Wallahbuallam

\section{DAFTAR PUSTAKA}

Alisjahbana, Sutan Takdir. 1966. Indonesia: Social and Cultural Revolution. Kuala Lumpur: Oxford University Press.

Al-Banjari, Syekh Arsyad. 1983. Tuhfat al-Râghibîn Banjarmasin: Toko Buku Murni.

Anonim. 2013. Kementerian Agama dalam Angka 2012. Jakarta: Pusat Informasi dan Hubungan Mayarakat Kemenag RI.

Bruinessen, Martin van. 1995. Kitab Kuning, Pesantren dan Tarekat. Bandung: Mizan.

Feener, R. Michael. 2013. "Hand, Heart and Handphone: State Shari'a in the Age of the SMS" Contemporary Islam 7: 15-32. 
Dari IAIN Ke UIN Pangeran Antasari: Tantangan dan Peluang di Tengah Arus Perubahan Sosial...

Kailani, Najib. 2012.'Forum Lingkar Pena and Muslim Youth in Contemporary Indonesia" Review of Indonesian and Malaysian Affairs Vol. 46 No.1: 33-53.

Lindsay, Jennifer dan Maya H.T. Liem. ed. 2012. Heirs to World Culture, Being Indonesian 1950-1965 Leiden: KITLV Press.

Mandan, Arief Mudatsir ed. 2008. Napak Tilas Pengabdian Idham Chalid Jakarta: Pustaka Indonesia Satu.

Mihardja, Achdiat K., ed. 1948. Polemik Kebudajaan Djakarta: Balai Pustaka.

Moertopo, Ali. 1978. Strategi Kebudayaan Jakarta: CSIS.

Mujiburrahman. 1999. "Islam and Politics in Indonesia: The Political Thought of Abdurrahman Wahid”' Islam and Christian Muslim Relations Vol. 10: 339-352.

Mujiburrahman. 2006. Feeling Threatened: Muslim-Christian Relations in Indonesia's New Order Amsterdam: Amsterdam University Press.

Mujiburrahman. 2008. Mengindonesiakan Islam: Representasi dan Ideologi. Yogyakarta: Pustaka Pelajar.

Mujiburrahman. 2013. Bercermin ke Barat: Pendidikan Islam Antara Ajaran dan Kenyataan. Banjarmasin: Jendela.

Muthalib, Abdul. 1995. "The Mystical Thought of Muhammad Nafis al-Banjari, an Indonesian Sufi of the Eighteenth Century" MA Thesis, McGill University.

Natsir, M. 1937. Cultuur Islam Bandoeng: Pendidikan Islam Bg. Penjiaran.

Pane, Armyn. 2005. Habis Gelap Terbitlah Terang. Jakarta: Balai Pustaka.

Rahmadi dkk. 2009. "Jaringan Intelektual Ulama Banjar Abad XIX dan XX: studi tentang proses, pola dan ekspansi jaringan.” Penelitian IAIN Antasari.

Rasjidi, Muhammad. 1980. Strategi Kebudayaan dan Pembaharuan Pendidikan Nasional Jakarta: Bulan Bintang.

Sani, Asrul. 1997. Surat-Surat Kepercayaan Jakarta: Pustaka Jaya.

Sjamsuddin, Helius. 2001. Pegustian dan Temenggung: Akar Sosial, Politik, Etnis dan Dinasti Perlawanan di Kalimantan Selatan dan Tengah. Jakarta: Balai Pustaka.

Sukarni. 2011. Fikih Lingkungan Hidup. Banjarmasin: Antasari Press.

Suyono, Haryono. 2011. "Ledakan Penduduk” Kompas, 5 April.

Syaharuddin. 2008. "Organisasi Islam di Borneo Selatan, 1912-1942: awal kesadaran berbangsa urang Banjar.” Tesis Master. Yogyakarta: Fakultas Ilmu Budaya, Universitas Gadjah Mada.

Syahrazad (Sjahrir). 1951. Renungan Indonesia Djakarta: Pustaka Rakjat.

Wajidi. 2007. Nasionalisme Indonesia di Kalimantan Selatan 1901-1942 Banjarmasin: Pustaka Banua. 
